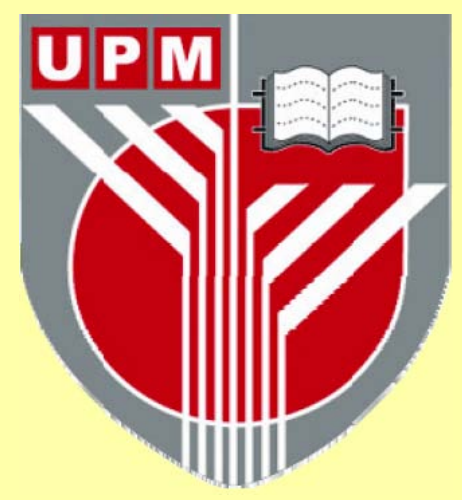

UNIVERSITI PUTRA MALAYSIA

A FAST SCHEDULING ALGORITHM

FOR WDM OPTICAL NETWORKS

CHEAH CHENG LAI

FK 200022 
A FAST SCHEDULING ALGORITHM

FOR WDM OPTICAL NETWORKS

By

CHEAH CHENG LAI

Thesis Submitted in Fulfilment of the Requirements for the

Degree of Master of Science in Faculty of Engineering

Universiti Putra Malaysia

July 2000 
To Siew Yeng and Zhiyi 
Abstract of the thesis presented to the Senate of Universiti Putra Malaysia in fulfilment of the requirement for the degree of Master of Science.

\section{A FAST SCHEDULING ALGORITHM FOR WDM OPTICAL NETWORKS}

By

\section{CHEAH CHENG LAI}

July 2000

\section{Chairman : Associate Professor Borhanuddin Mohd. Ali, Ph. D.}

Faculty : Engineering

Wavelength Division Multiplexing (WDM) is emerging as the most promising approach to exploit the huge bandwidth of optical fibre. This approach divides the optical spectrum into many different channels where each channel corresponds to a different wavelength. Single-hop WDM networks are attractive in local area environment where all the nodes can be connected to a single broadcast facility. In a single-hop WDM broadcast network, the transmitter must know when to transmit a packet and at which wavelength, while the receiver must know when to tune to the appropriate wavelength to receive the packet. This process requires some form of coordination. Many researches have focused on the scheduling algorithms that perform this kind of coordination.

This thesis proposes a scheduling algorithm for the WDM broadcast networks. The algorithm employs a theory in graph, known as edge colouring of bipartite multigraph to produce the transmission schedule, which is free from collision due to the nature of the edge colouring. An optimal edge colouring of bipartite multigraph can be found in $\mathrm{O}\left(M \log ^{2} N\right)$ time, where $M$ is number of 
packets selected for scheduling, and $N$ is the number of the nodes. This time complexity can be improved to $\mathrm{O}\left(\log ^{3} N\right)$ by parallel processing using $\mathrm{O}(M)$ processors.

Two variations of implementation of the scheduling algorithm have been proposed, namely the Variable Frame Size (VFS) and Limited Frame Size (LFS) schemes. These schemes use different criteria to select packets from the nodes for scheduling. The VFS scheme is simple, but supports only best effort transmissions. The LFS scheme ensures the frame size of the transmission schedule is bounded, thus enabling it to support bandwidth guarantee to the nodes up to a node's fair share of the network capacity. The LFS scheme is capable of supporting constant bit rate and unspecified bit rate service categories, analogous to the Asynchronous Transfer Mode (ATM) services.

The results show that the LFS scheme performs better than the VFS scheme in terms of channel utilisation, packet loss probability and network throughput for all the simulated traffic patterns, especially at heavy loads. Besides, the LFS scheme respects any level of bandwidth guarantee, while the unused bandwidth can be used for best effort transmissions. The results also show that the VFS and LFS schemes are future-proof as they are able to capitalise on the increase in the number of wavelength channels. 
Abstrak tesis yang dikemukakan kepada Senate Universiti Putra Malaysia sebagai memenuhi keperluan untuk ijazah Master Sains.

\section{SUATU ALGORITMA PENJADUALAN PANTAS UNTUK RANGKAIAN- RANGKAIAN OPTIK WDM}

Oleh

\section{CHEAH CHENG LAI}

Julai 2000

\section{Pengerusi : Profesor Madya Borhanuddin Mohd. Ali, Ph. D. \\ Fakulti : Kejuruteraan}

Pemultipleksan pembahagian panjang gelombang (WDM) sedang muncul sebagai pendekatan yang terjamin untuk mengeksploitasi lebar jalur optik gentian yang amat besar. Pendekatan ini membahagikan spektrum optik kepada beberapa saluran yang berbeza, di mana setiap saluran mewakili satu panjang gelombang yang berlainan. Rangkaian-rangkaian WDM satu lompatan adalah menarik dalam persekitaran tempatan di mana semua nodnya boleh disambungkan kepada satu kemudahan penyiaran. Dalam satu rangkaian WDM satu lompatan, penghantar perlu tahu bila hendak menghantarkan satu paket pada panjang gelombang yang tertentu, sementara itu penerima perlu tahu bila hendak menala pada panjang gelombang yang sesuai untuk menerima paket tersebut. Proses ini memerlukan beberapa bentuk koordinasi. Banyak penyelidikan telah ditumpukan pada algoritma-algoritma penjadualan dalam melaksanakan koordinasi ini.

Tesis ini mencadangkan satu algoritma penjadualan untuk rangkaianrangkaian WDM satu lompatan. Algoritma ini menggunakan satu teori graf yang dikenali sebagai perwarnaan pinggir dalam graf dwibahagian untuk menghasilkan 
jadual penghantaran, yang bebas dari pelanggaran disebabkan oleh tabii perwarnaan pinggir. Satu perwarnaan pinggir yang optimum untuk graf dwibahagian boleh diperolehi dalam masa $\mathrm{O}\left(\operatorname{Mog}^{2} N\right)$, di mana $M$ adalah bilangan paket yang terpilih untuk penjadualan dan $N$ adalah bilangan nod. Kompleksiti masa ini boleh dipertingkatkan kepada $\mathrm{O}\left(\log ^{3} N\right)$ dengan proses selari dengan menggunakan $\mathrm{O}(M)$ pemproses.

Dua variasi pelaksanaan algoritma penjadualan telah dicadangkan, iaitu skima Variable Frame Size (VFS) dan Limited Frame Size (LFS). Skima-skima ini menggunakan kriteria yang berbeza dalam pemilihan paket dari nod-nod untuk penjadualan. Skima VFS adalah mudah tetapi ia cuma boleh menyokong penghantaran usaha terbaik. Skima LFS memastikan saiz bingkai jadual penghantarannya adalah terbatas, dengan demikian ia dapat menampung lebar jalur jaminan kepada nod-nodnya sehingga satu nod mempunyai bahagian adil kapasiti rangkaian. Skima LFS berupaya menyokong kategori perkhidmatan kadar bit malar dan kadar bit tidak ditetap, beranalog dengan perkhidmatan mod penghantaran tak segera (ATM).

Keputusan menunjukkan bahawa skima LFS berprestasi lebih baik daripada skima VFS dari segi penggunaan saluran, kebarangkalian hilang paket dan daya memproses untuk semua corak trafik yang diselakukan, terutamanya pada bebanan yang berat. Selain itu, skima LFS sesuai untuk sebarang paras lebar jalur jaminan, manakala lebar jalur yang tidak digunakan boleh diguna untuk penghantaran usaha terbaik. Keputusan juga menunjukkan bahawa skima VFS dan LFS adalah tahan untuk masa depan kerana ia dapat mengambil kesempatan pada penambahan bilangan saluran jarak gelombang. 


\section{ACKNOWLEDGEMENTS}

I would like to take this opportunity to thank everyone who has directly or indirectly contributed to this thesis. The following list, by no means exhaustive, is an attempt to acknowledge at least a few of them.

First and foremost, I wish to express my deepest gratitude and appreciation to Associate Prof. Dr. Borhanuddin Mohd. Ali, the chairman of my supervisory committee for his guidance and inspiration throughout the research period.

I am also grateful to my supervisor Dr. Veeraraghavan Prakash for his kind supervision and invaluable suggestions for carrying out the work properly.

My sincere thanks to my supervisor Dr. Selvakennedy Selvadurai for his earnest discussions and constructive suggestions. He has suggested and helped on the development of the simulation system and provided comments on the results.

My sincere thanks also to Prof. Dr. Malay Raj. Mukerjee for ideas and suggestions he has contributed to this work. He was my supervisor before he left Malaysia in March 2000.

Lastly, I wish to take this opportunity to express my sincere gratitude to all my fellow friends in ATM \& Broadband Research Group for their help, friendship and insightful discussion, especially Mr. Ali Mohamed Abdelrahman and Mr. Choong Khong Neng. 
I certify that an Examination Committee met on $31 \mathrm{July,} 2000$ to conduct the final examination of Cheah Cheng Lai on his Master of Science thesis entitled "A Fast Scheduling Algorithm for WDM Optical Networks" in accordance with Universiti Pertanian Malaysia (Higher Degree) Act 1980 and Universiti Pertanian Malaysia (Higher Degree) Regulations 1981. The Committee recommends that the candidate be awarded the relevant degree. Members of the Examination Committee are as follows:

ABDUL RAHMAN RAMLI, Ph.D.

Lecture

Faculty of Engineering

Universiti Putra Malaysia

(Chairman)

BORHANUDDIN MOHD. ALI, Ph.D.

Associate Professor

Faculty of Engineering

Universiti Putra Malaysia

(Member)

VEERARAGHAVAN PRAKASH, Ph.D.

Lecturer

Faculty of Engineering

Universiti Putra Malaysia

(Member)

SELVAKENNEDY SELVADURAI, Ph.D,

Head of Unit

Telekom Malaysia Photonics Research Centre

Telekom Malaysia Berhad

(Member)

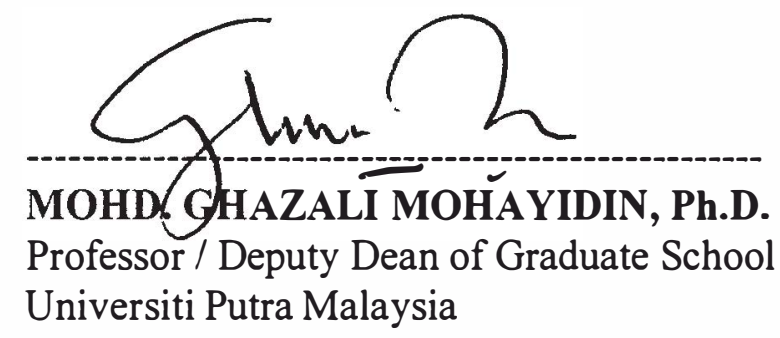

Date: 08 AUG 2000 
This thesis was submitted to the Senate of Universiti Putra Malaysia and was accepted as fulfilment of the requirements for the degree of Master of Science.

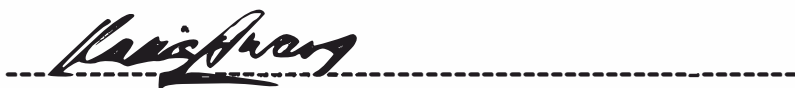

KAMIS AWANG, Ph.D.

Associate Professor / Dean of Graduate School Universiti Putra Malaysia

Date: 11 NOV 2000 
I hereby declare that the thesis is based on my original work except for quotations and citations which have been duly acknowledged. I also declare that it has not been previously or concurrently submitted for any other degree at UPM or other institutions.

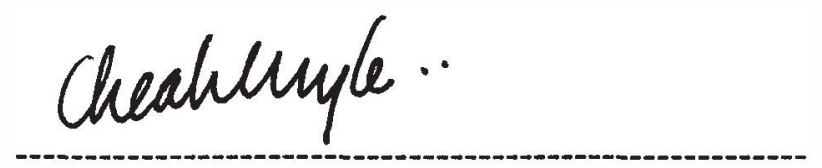

CHEAH CHENG LAI

Date: 11 August, 2000 
TABLE OF CONTENTS

Page

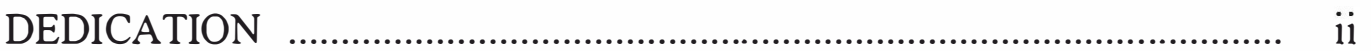

ABSTRACT ………...............................................................

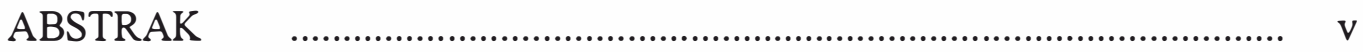

ACKNOWLEDGEMENTS ……………………………………......... vii

APPROVAL SHEETS ………………………………........................... viii

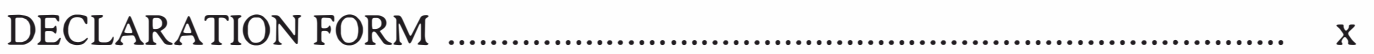

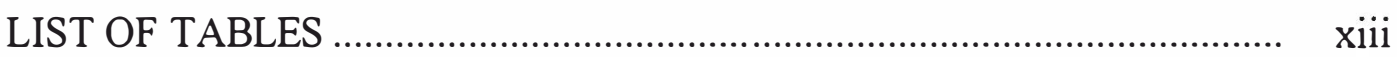

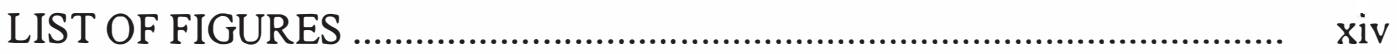

LIST OF ABBREVIATIONS ............................................................. $\quad$ xvii

LIST OF NOTATIONS ….................................................................. xix

\section{CHAPTER}

INTRODUCTION 1

WDM Optical Networks ...................................................... 1

WDM Broadcast-and-Select Optical Networks .................... 3

Physical Layer Architecture ....................................... 4

Single-Hop and Multihop ......................................... 4

Network Classification ................................................ 5

Optical Devices for WDM Broadcast Networks .................. 6

Optical Amplifier ........................................................ 6

Transceivers .............................................................. 6

Integrated Star Coupler ............................................... 7

WDM Broadcast Networks Testbeds ................................... 8

IBM Rainbow Projects ............................................... 9

APRA AON …………………………………...... 9

Motivation and Challenge ..................................................... 11

Efficient Scheduling Algorithm ................................ 12

Graph Theory ............................................................ 13

Parallel Computing ………………………………... 14

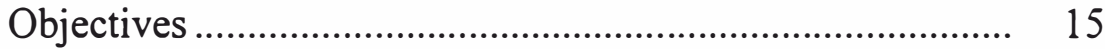

Organization ................................................................ 15

2 LITERATURE REVIEW 17

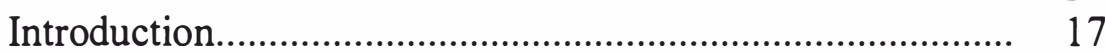

Notations and Definition in Graph Theory ......................... $\quad 17$

Parallel Algorithms .......................................................... 22

Algorithms and Complexity ..................................... 23

Efficiency Parallel Algorithms .................................. $\quad 25$

The Model of Parallel Computation ............................ $\quad 25$

PRAM Model of Parallel Computation ........................ 27

PRAM Algorithmic Techniques ................................ 29

PRAM Algorithms ................................................. $\quad 30$ 
Scheduling Algorithms for WDM Broadcast Networks....... 35

Scheduling Algorithms with Transceivers Tuning

Latency

Scheduling Algorithms with Negligible Transceivers

Tuning Time

Distributed Scheduling Algorithms ........................ 46

Summary

RESEARCH METHODOLOGY 49

Introduction................................................................. 49

Network Architecture ..................................................... 49

Scheduling Algorithm .................................................. 52

The Parallel edge Colouring Algorithm ........................... 55

Euler-Colour Sub-Algorithm .................................... 55

The Optimal Edge Colouring Algorithm .................. 59

Implementation ........................................................ 61

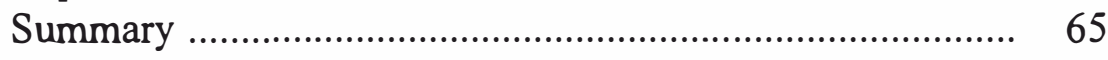

4 SIMUALTION MODEL 66

Introduction................................................................ 66

Model Description and Operating Assumptions.................. 66

System Parameters........................................................... 69

Performance Metrics................................................... 72

Summary .............................................................. 73

$5 \quad$ RESULTS AND DISCUSSIONS $\quad 74$

Introduction................................................................. 74

Transient Effect of the Simulation ................................... 75

Frame Size Variability ................................................ 78

Impact of Traffic Load Variation ..................................... 81

Bandwidth Reservation Capability .................................. 86

Effect of Different Number of Wavelength Channels ......... 88

Effect of packet Selection factor ..................................... 91

Summary................................................................. 95

6 CONCLUSIONS AND FUTURE WORK 98

Main Contribution of the Thesis ....................................... 98

Future Work ............................................................. 100

Parallel Processing ................................................ 101

Input-Queue Switches with No Speedup .................. 101

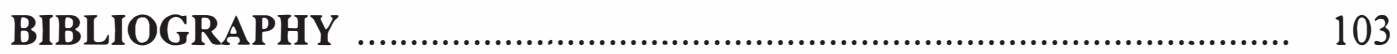

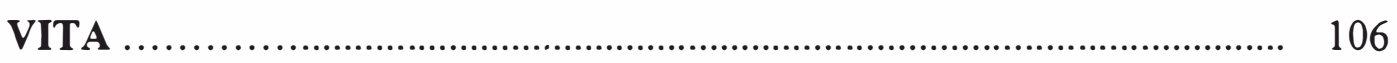




\section{LIST OF TABLES}

$\begin{array}{lll}\text { Table Page } & \text { Pan }\end{array}$

1 Comparison of the time complexity of the different scheduling 47 algorithms. 


\section{LIST OF FIGURES}

Figure

Page

1 An illustration of the WDM network concept.

2 WDM broadcast network's physical layer architecture.

(a) Star topology and (b) bus topology. 5

3 ARPA AON network architecture. 10

$4 \quad$ Example of a (a) graph, (b) multigraph, and (c) pseudograph. $\quad 18$

$5 \quad$ The Parallel Random Access Machine (PRAM). 28

6 The prefix computation in which the operation * is addition. 32

7 List ranking algorithm for a list of seven elements. 34

$8 \quad$ The operation of MULTIFIT. (a) Normalised traffic matrix and (b) 39 matrix $s$, where $s_{i l}$ is the number of time slots that node $i$ needs to transmit on channel $l$.

9 (a) A cyclic-shift schedule, and (b) an optimal cyclic-shift schedule

10 The conceptual representation of the model network. The network consists of $N$ nodes, each connected to a passive star coupler via a two-way fibre. The data channels are denoted as $\lambda_{1}, \lambda_{2}, \ldots, \lambda_{W}$ and the control channel is denoted as $\lambda_{c}$.

11 (a) a $4 \times 4$ traffic matrix, and (b) the traffic matrix is modelled by a bipartite multigraph.

12 The transmission schedule produced by edge colouring the graph in Figure 2(b) assuming $W \geq N$.

13 A Euler Partitioning. (a) a bipartite multigraph, and (b) the graph is partitioned into cycles and paths.

14 One decomposition stage of the Euler-colour. (a) The Euler partition of the input graph is labelled with 0 and 1 alternatively along each path and cycle. (b) $G_{1}$ is obtained by all edges labelled 0 , and (c) $G_{2}$ is obtained by all edges labelled 1 . 
15 The input representation. (a) a bipartite multigraph, and

(b) the adjacency lists.

16 Bandwidth allocation table. $T 1$ to $T 4$ denote the transmitters for node 1 to node 4 and $R 1$ to $R 4$ denote the receivers for node 1 to node 4 . The $(i, j)$ entry denotes the allocated bandwidth in term of the number of packets per cycle.

17 The block diagram of the simulation system.

18 The pattern of packet loss probability of the VFS scheme for Bermoulli traffic over 1,000 cycles of scheduling.

19 The pattern of packet loss probability of the LFS scheme for Bernoulli traffic over 1,000 cycles of scheduling.

20 The pattern of packet loss probability of the VFS scheme for 2-state traffic over 1,000 cycles of scheduling.

21 The pattern of packet loss probability of the LFS scheme for 2-state traffic over 1,000 cycles of scheduling.

22 Average frame size of the VFS and LFS schemes against packets arrival rates for Bernoulli traffic.

23 Average frame size of the VFS and LFS schemes against packets arrival rate for Poisson traffic.

24 Average frame size of the VFS and LFS schemes against packets arrival rate for 2-state traffic.

25 Channel utilisation of the VFS and LFS schemes against packet arrival rates for Bemoulli traffic.

26 Channel utilisation of the VFS and LFS schemes against packet arrival rates for Poisson traffic.

27 Channel utilisation of the VFS and LFS schemes against packet arrival rates for 2-state traffic.

28 Packet loss probability of the VFS and LFS schemes against packet arrival rates for Bernoulli traffic.

29 Packet loss probability of the VFS and LFS schemes against packet arrival rates for Poisson traffic. 
30 Packet loss probability of the VFS and LFS schemes against packet arrival rates for 2-state traffic.

31 Packet loss probability of the LFS scheme against different ratios of reserved traffic.

32 Packet loss probability of the LFS scheme with $50 \%$ reserved traffic against different packet arrival rates of Bernoulli and 2-state traffic.

33 Network throughput of the VFS and LFS schemes against number of wavelength channels for Bernoulli traffic.

34 Network throughput of the VFS and LFS schemes against number of wavelength channels for Poisson traffic.

35 Network throughput of the VFS and LFS schemes against number of wavelength channels for 2-state traffic.

36 The channel utilisation of the VFS and LFS schemes against packet selection factor, $k$ for Bernoulli traffic.

37 The channel utilisation of the VFS and LFS schemes against packet selection factor, $k$ for 2 -state traffic.

38 The packet loss probability of the VFS and LFS schemes against packet selection factor, $k$ for Bernoulli traffic.

39 The packet loss probability of the VFS and LFS schemes against packet selection factor, $k$ for 2-state traffic.

40 Switching element with input queues. 


\section{LIST OF ABBREVIATIONS}

\begin{tabular}{|c|c|c|}
\hline ARPA & - & Advanced Research Project Agency \\
\hline ARPA AON & - & ARPA sponsored All Optical Network \\
\hline ATM & - & Asynchronous Transfer Mode \\
\hline CBR & - & Constant Bit Rate \\
\hline CRCW & - & Concurrent Read, Concurrent Write \\
\hline CREW & - & Concurrent Read, exclusive Write \\
\hline EDFA & - & Erbium-Doped Fibre Amplifier \\
\hline EREW & - & Exclusive Read, Exclusive Write \\
\hline FT-FR & - & Fixed Transmitter(s) and Fixed Receiver(s) \\
\hline FT-TR & - & Fixed Transmitter(s) and Tuneable Receiver(s) \\
\hline LAN & - & Local Area Network \\
\hline LFS & - & Limited Frame Size \\
\hline IP & - & Internet Protocol \\
\hline MAN & - & Metropolitan Area Network \\
\hline MIMD & - & Multiple-Instruction, Multiple-Data stream \\
\hline NC & - & Nick (Pippenger)'s Class \\
\hline NP & - & Non-deterministic Polynomial \\
\hline OT & - & Optical Terminal \\
\hline PE & - & Processing Element \\
\hline PRAM & - & Parallel Random Access Machine \\
\hline QoS & - & Quality of Service \\
\hline SCMA & - & Subcarrier Division Multiple Access \\
\hline
\end{tabular}




$\begin{array}{lll}\text { SIMD } & - & \text { Single-Instruction, Multiple Data stream } \\ \text { TDMA } & - & \text { Time Division Multiple Access } \\ \text { TT-FR } & - & \text { Tuneable Transmitter(s) and Fixed Receiver(s) } \\ \text { TT-TR } & - & \text { Tuneable Transmitter(s) and Tuneable Receivers(s) } \\ \text { UBR } & - & \text { Unspecified Bit Rate } \\ \text { VC } & - & \text { Virtual Circuit } \\ \text { VFS } & - & \text { Variable Frame Size } \\ \text { WAN } & - & \text { Wide Area Network } \\ \text { WDM } & - & \text { Wavelength Division Multiplexing } \\ \text { WDMA } & - & \text { Wavelength Division Multiple Access }\end{array}$




\section{LIST OF NOTATIONS}

$\Delta \quad-\quad$ Maximum degree.

$\lambda \quad$ - Wavelength channel.

$\lambda_{c} \quad-\quad$ Control channel.

$\chi \quad-\quad$ Chromatic number.

$f \quad-\quad$ Frame size.

$f_{\max } \quad-\quad$ Maximum frame size of the LFS scheme.

C - $\quad$ Set of colours.

$C G \quad$ - $\quad$ Coloured edges.

CU - Channel Utilisation.

e $\quad$ - Edge.

E - - Set of edges.

$k \quad$ - $\quad$ Packet selection factor.

G - Graph.

$l \quad$ - Burst length of 2-state traffic.

$M \quad$ - $\quad$ Number of packets selected for scheduling.

$N \quad$ - Number of nodes.

$p \quad-\quad$ Probability.

$P G \quad$ - $\quad$ Total number of packets generated.

PL - Total number of packets lost.

$p_{P L} \quad-\quad$ Packet loss probability.

PS - Total number of packets been transmitted. 
$S G \quad-\quad$ Subgraph.

$t_{A} \quad-\quad$ Interarrival time of the packets of Poisson traffic.

$T P \quad$ - $\quad$ Network throughput.

TS - $\quad$ Total number of time slots.

u - $\quad$ Source node.

$U \quad$ - $\quad$ Set of source nodes.

$U G \quad$ - $\quad$ Uncoloured edges.

$v \quad-\quad$ Destination node.

$V \quad$ - $\quad$ Set of destination nodes.

W - Number of wavelength channels for data transmission. 


\section{CHAPTER 1}

\section{INTRODUCTION}

\section{WDM Optical Networks}

The demand for bandwidth in networks is increasing at a tremendous rate. The high demand for bandwidth is driven by the emergence of new services and requirements such as high-definition television, digital audio, medical-imaging, supercomputer interconnect and digital library (Li and Stone, 1999). Optical fibre has evolved to become the transmission medium of choice for high-speed communications. The emergence of optical fibre as the transmission medium stems from several key attributes, which are low bit error rates, enormous bandwidth and low cost.

In optical networks, the end-user equipment are based on electronic, thus the maximum rate at which each end-user can access the networks is limited by the electronic speed. The key in designing the optical networks in order to exploit the huge bandwidth of fibre optic is to introduce concurrency among multiple-user transmissions into the network. There are many approaches to introduce this concurrency, such as Time Division Multiple Access (TDMA), Subcarrier Multiple Access (SCMA) and Wavelength Division Multiple Access (WDMA).

TDMA divides the optical bandwidth into sequential time slots. Time slots may be pre-assigned to users or they may be allocated on a demand basis, depending 
on the type of transfer mode being used. SCMA uses different electrical subcarrier frequencies to multiplex separate data streams. The different subcarriers then modulate an optical carrier. TDMA and SCMA have been investigated by a number of authors (Green, 1993), and their limitation is due to the electronic front-ends employed at the network nodes, which are limited by the peak electronic rate of a few gigabits per second (Mukherjee, 1992).

WDMA divides the optical spectrum into many different channels, where each channel corresponds to a different wavelength. The technique used in this approach is known as Wavelength Division Multiplexing (WDM). The WDM networks may comprise from several channels up to several tens of channels at different wavelengths, each could be operated at the peak electronic rate. To date, WDMA appears to be the most promising approach to exploit the huge bandwidth of fibre optic (Mukhejee, 1992), since all the end-user equipment needs to operate only at the bit rate of a single channel.

Figure 1 shows an illustration of the WDMA concept. It shows an optical network where connections between different node-pairs are established at different wavelengths, which are $\lambda_{1}, \lambda_{2}$ and $\lambda_{3}$.

Fibre optic has two low-loss wavebands of approximate widths of $100 \mathrm{~nm}$ and $150 \mathrm{~nm}$ in the $1.3 \mu \mathrm{m}$ and $1.5 \mu \mathrm{m}$ waveband regions, respectively (Green, 1993). A direct conversion from wavelengths to frequencies yields an aggregate bandwidth of these regions to be approximately $30 \mathrm{THz}$. Using a modulation rate of $1 \mathrm{~b} / \mathrm{Hz}$, this bandwidth translates to $30 \mathrm{~Tb} / \mathrm{s}$. Parallel and concurrently operating WDM channels 
can be derived by having end-users transmit into and receive from the nonoverlapping portions of the fibre low loss spectrum.

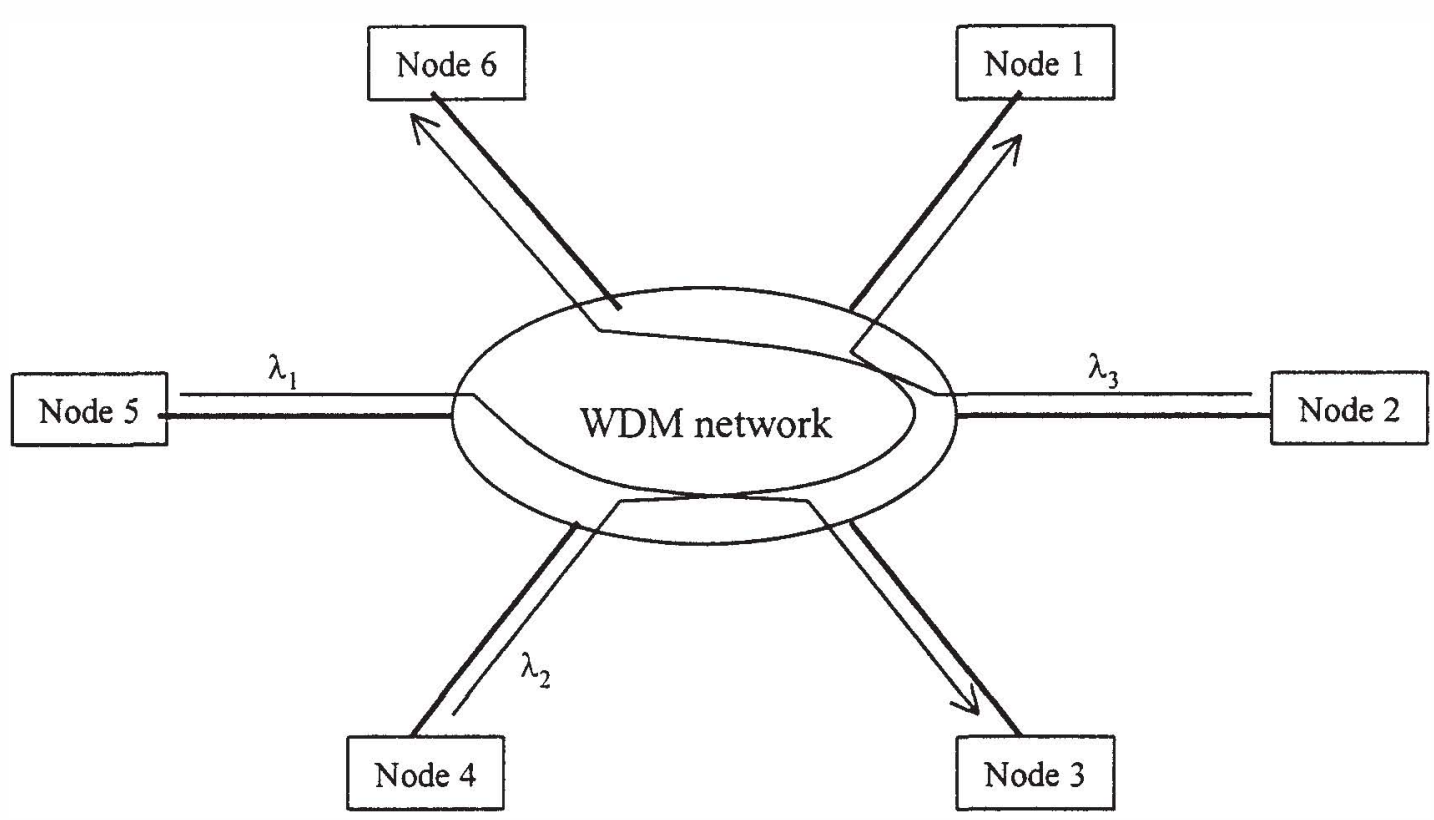

Figure 1: An illustration of the WDM network concept.

\section{WDM Broadcast-and-Select Optical Networks}

A simple physical architecture to implement a WDM network is based on broadcast-and-select approach. In this approach, the transmission from a node is broadcast to all the nodes in the network. At the receiver end, the desired signal is then extracted from the entire signal spectrum. These networks are "all optical" in nature, whereby once information enters the networks, it remains in the optical domain until it is delivered to its destination. The WDM broadcast-and-select optical networks sometimes are also known as WDM broadcast networks. 


\section{Physical Layer Architectures}

The WDM broadcast networks' fabric can be totally passive, consisting of optical couplers (combiners and splitters) that formed various physical topologies. Figure 2 shows two of the most common topologies, which are star and bus. The star topology is configured as a broadcast-and-select network in which all of the inputs from various nodes are combined in a passive star coupler, and the mixed optical information is then broadcast to all outputs. In the bus topology, each node transmits into the bus through a coupler and receives from the bus via another coupler.

The star topology is attractive because it is more efficient in distributing the optical power due to the logarithmic splitting loss in the coupler, since the splitter portion of the star coupler is essentially a binary tree structure (Mukherjee, 1992). In addition, an $N \times N$ star coupler can be considered to consist of an $N \times 1$ combiner followed by a $1 \times N$ splitter. Thus, a signal strength incident from any input can be (approximately) equally divided among all the $N$ outputs.

\section{Single-Hop and Multihop}

The WDM broadcast networks may be categorised into single-hop or multihop (Mukherjee, 1992). In the single-hop networks, each node has a direct link to every other node, while in the multihop networks, two nodes may communicate via one or more intermediate nodes.

The multihop networks have the advantage that not every node has to be capable of accessing every channel of the networks, reducing the requirements of its transceivers. However, messages may have to be routed through one or more 